\title{
Editorial
}

\section{Safety at sea: a forgotten frontier?}

Every year 1100 people drown accidentally in the United Kingdom ${ }^{1}$; more than a quarter (up to $40 \%$ in Scotland) occur in coastal and offshore water. ${ }^{12}$ Activities that expose groups to risk-above, on, and beneath the sea surface-may be regarded as either recreational or industrial; the former amount to $83 \%$ of coastguard effort whereas industrial (commercial) incidents account for the remainder. ${ }^{3}$ The land area of the United Kingdom ranks only 53rd out of 123 maritime countries but jurisdictional area (902 000 sq miles) within the 200 nautical mile exclusive economic zone is ranked 10 th. ${ }^{4}$ Moreover, the United Kingdom coastline (2790 nautical miles)-in 11 th place- is even longer than that of India.

Such facts emphasize the ease of access-actual and potential - to the beaches and the seas beyond. Unrestricted access presents hazards, risks, and governmental responsibilities to create and maintain an acceptably safe environment for those exposed to risk. Who is responsible for safety at sea? What hazards and risks confront marine commercial activities? And what strategy might be adopted to reduce loss of life and property at sea?

The Marine and Ports Directorate of the Department of Transport (DTp) has overall responsibility ${ }^{5}$ but 98 other organisations, excluding local authorities, have particular commitments. ${ }^{6}$ The Directorate's Marine Survey Service and its Marine Emergency Operations and Pollution Control Unit have health and safety functions which are guided by the principal Merchant Shipping Acts and Statutory Instruments. ${ }^{7}$ The DTp also promulgates Merchant Shipping Notices for guidance in the safe conduct of maritime activities. ${ }^{8}$

An exception to DTp responsibility dates from 1976 when the Health and Safety at Work etc Act 1974 (HSAWA) was extended to the offshore oil and gas industry, including divers. ${ }^{9}$ This charged the Health and Safety Commission (HSC) with responsibility for offshore installations. The Petroleum Engineering Directorate of the Department of Energy-acting as agents for HSC-discharges this occupational safety function. ${ }^{10}$ All merchant ships and fishing vessels not tied up at the quayside, however, remain within the scope of the DTp where only the Merchant Shipping Acts apply.
Industry at sea may be considered either as resource extraction and exploitation-oil, gas, and fishing-or as commercial transport including passenger carrying operations. The scale and distribution of the associated hazards are immense.

In the oil and gas industry fatal and non-fatal accident experience from 1974 to 1978 was reviewed by the Burgoyne Committee set up to assess the Department of Energy's safety regulations. ${ }^{11}$ The incidence of all accidents affecting offshore workers was half the rate for coal miners but twice that for manufacturing industry. Fatalities from falls overboard alone decreased from 0.57 (1975-9) to 0.27 per 1000 at risk (1979-83) (A Gillam, 4th Annual Offshore Search and Rescue Communications Conference, Leith, 1985). Between 1971 and 1983, 34 fatal accidents involving United Kingdom commercial divers were reported, of which $24(70 \%)$ occurred before 1977 when the Health and Safety at Work etc Act 1974 applied. Mean fatal accident rates for commercial divers declined from 8.8 per 1000 (1971-6) to $1 \cdot 1$ per 1000 (1977-83) and only three diving deaths have occurred since 1979 (M S J Reilly, unpublished observations). Findings for 1971-6 accord with previously reported death rates for $1970-4^{12} 13$ when North Sea diving was in its early ${ }^{14}$ and most dangerous stage.

Until 1979, but possibly later, naval architects seemed unaware of the order of magnitude of United Kingdom fishing vessel loss rates. ${ }^{15}$ An apparently increased incidence of losses (1961-80) was reported in $1984^{16}$ and the naval architectural implications have now been acknowledged. ${ }^{17}$ This increase occurred despite the recommendations of the Committee of Inquiry into Trawler Safety (CITS) in $1969^{18}$ and the phased introduction of the 1975 Fishing Vessels (Safety Provisions) Rules. ${ }^{19}$ In 1985 the DTp commissioned research to investigate the factors contributing to vessel losses but the findings have not yet been disclosed. Between 1981 and 1985, 226 fishing vessels were lost. ${ }^{20}$ Loss rates appear to be stabilising now but still remain $60-70 \%$ higher than those which prevailed when the Committee of Inquiry into Trawler Safety reported. Elsewhere in this issue (p7) inadequacies in the procedure for investigating marine losses in general, and fishing vessel losses in particular, are described. ${ }^{21}$ The time is 
ripe for radical change in the accident investigation procedure: aviation safety authorities have shown a lead and offered a blueprint. ${ }^{22}$

A review of total accident mortality experience for United Kingdom fishermen (1961-80) showed some reduction in the fatal personal accident rate for fishermen on medium sized and small boats $(<24$ metres) but the post Committee of Inquiry into Trawler Safety all causes accident rate, disregarding vessel size, increased slightly. ${ }^{23}$ From 1981 to 1985 there were 112 fatal accidents, corresponding with a mean mortality rate of 1.0 per $1000 .^{20}$ Fifty per cent of total accident mortality in the industry had less to do with direct physical environmental influences on boats (the "Act of God" mentality) but rather more to do with traumatic amputation of limbs owing to inadequate or absent machinery guards; skull and spinal injuries rendered by falls from ill designed ladders or into unprotected hatchways; and drowning from falls overboard made more likely by inadequate or missing guard rails. Once overboard, survival is hampered by the absence of lifejackets, thermal protection, and personal locator beacons. Fishing boats are still not required to carry immersion suits for emergency use and, although survival training is now more widespread,${ }^{24}$ it is below the standards of the oil industry and it is still not compulsory. These avoidable shortcomings ignore the effects of hypothermia, ${ }^{25-29}$ particularly in the North Sea, ${ }^{30} 31$ and the value of survival training. ${ }^{32}$ Furthermore, within the apparent safety of ports, accidents and drownings still occur-possibly because of inadequate ship to shore access and poor artificial lighting. ${ }^{33} 34$ The Health and Safety Commission has proposed regulations governing the loading and unloading of fishing boats at the quayside but not for fishing operations at sea. ${ }^{35}$ At sea, where the accident risks are greater, the Factory Inspectorate does not have the authority or, apparently, the intention to be concerned. This anomaly is compounded by the lack of any effort at sea by the DTp to detect and prosecute boats infringing minimal health and safety standards. And yet the ability to police legislation at sea is proved: officers of the Fishery Protection Squadron regularly board fishing boats to monitor compliance with far more intricate laws governing mesh size of nets and EEC fish quota restrictions.

The title of the recent well intentioned but very restricted statute- the Safety at Sea Act $1986^{36}$ conveys an erroneous impression of all embracing legislation. This Act will require the fitting of automatically releasing liferafts and emergency position indicating radio beacons on fishing boats but the opportunity to introduce equally necessary items, such as the compulsory wearing of lifejackets, was strongly opposed by industry representatives or ignored by the DTp.

Pre-employment medical examination is compul- $\frac{\mathbb{D}}{\circ}$ sory for merchant seamen, ${ }^{37}$ commercial divers, ${ }^{38} \overrightarrow{\vec{F}}$ and pilots. ${ }^{39}$ But fishermen require neither examination nor even health screening-an omission? which is at variance with DTp requirements for $\frac{\overline{\bar{c}}}{\mathrm{~s}}$ seafarers ${ }^{37}$ and with occupational health practice $\frac{\bar{\phi}}{\bar{\sigma}}$ elsewhere ${ }^{40}$ One fifth of all deaths of fishermen at sea $\mathbb{\complement}$ are due to undisclosed disease. ${ }^{23}$ Gastrointestinal ${ }^{4142} \mathrm{\omega}$ and respiratory ${ }^{4143}$ illnesses account for most $\vec{\circ}$ emergency treatment but genitourinary, psychiatric, and cardiovascular morbidity is also frequent. ${ }^{42} \vec{\omega}$ Physically disabled (one armed ${ }^{44}$ and one eyed ${ }^{41}$ ) fishermen have been found working at sea. Medical迹 evacuations and emergency admissions for epi- 3 lepsy, ${ }^{42}$ diabetes mellitus, ${ }^{45}$ acute asthma, ${ }^{45}$ mitral + stenosis precipitating congestive cardiac failure, ${ }^{45^{\circ}}$ dental abscess, ${ }^{45}$ and caries $^{43}$ not only waste $\vec{\circ}$ resources but also place search and rescue (SAR) crews at entirely avoidable risk. All of these ${ }_{C}$ detectable medical conditions preclude or restrict $\frac{\rho}{5}$ employment in other marine industries.

The number, type, and distribution of merchant shipping losses, up to 50 miles from the British coast, $\overrightarrow{0}$ was investigated for the period 1970-9.46 Accident "black spots" included the Thames and Humber estu-aries but, without standardisation for differentialo exposure to risk, these might merely reflect zones with greater density of traffic.

Commercial activity is not restricted to the sea sur-气 face: helicopter use in support of North Sea oper-음 ations is likely to remain high because of helicopter $\overrightarrow{0}$ versatility ${ }^{47}$ and because $75 \%$ of oil and gas person- 3 nel in the 1990s will be based more than 100 nautical miles offshore (RG Procter, Edinburgh conference, 1985). Helicopter accident experience per 1000000 hours exposure is between five and 50 times greater 3 than that of fixed wing jet aircraft. ${ }^{47}$ About $60 \%$ of helicopter accidents has been attributed to "pilot error" and, increasingly, the ergonomic aspects of North Sea flying operations arouse concern. ${ }^{4849}$ The contention that over-water safety is further compro-o mised by the risks of pilot ill health arising from in flight environmental hazards of noise, vibration, heat, and other factors (including seat and control layout) is under joint investigation coordinated by the Civilo Aviation Authority. Helicopter ditching experienceN and factors influencing post-ditching survival in the N North Sea (1970-83) have been discussed. 475051

Risks to ship and aircraft crews and to passengers travelling on and over the sea justify attention. Firstly, the inadequacies of legislation governinges? medical supplies aboard ships ${ }^{52-54}$ and the absence of basic equipment and drugs for life threateningo emergencies on passenger ferries have been illu- $-\vec{D}$ minated by recent debate. ${ }^{55-60}$ Medical or nursing 
presence is not required on ships at sea for up to 24 hours with more than 1000 passengers. Even when search and rescue (SAR) craft have medical expertise on board, the difficulties of administering first aid in a helicopter ${ }^{6162}$ (auscultation is virtually impossible) or on a lifeboat are considerable. A modern lifeboat, unless one of the large ones, is ".... not equipped to treat sick persons on board." ${ }^{3}$ Whichever mode of emergency transport is chosen, management is difficult and may well end in the death of the patient. ${ }^{64}$ Secondly, the ability to evacuate high sided passenger ferries in accordance with regulationsrequiring the clearance of 1.500 persons on board within 30 minutes of the decision to abandon shiphas been rigorously questioned. ${ }^{65}$ Recommendations enabling rapid evacuation include the installation of helidecks, inflatable chutes, and canopied liferafts additional to rigid hull lifeboats. Thirdly, new dimensions of risk to commercial aircraft arise from inflight engine shut down on extended range twin jet operations which will be permitted on transoceanic routes. ${ }^{6667}$ The frequency of engine shut downs is low ( 0.05 per 1000 hours $)^{68}$ but certification authorities apply the " 60 minute rule" so that, after single or double engine failure, there is an opportunity to "glide" to an airfield within a 60 minute radius. ${ }^{67}$ Because this demands more northerly routeings for twin jets on transatlantic routes, it means, in the event of controlled ditching, less tolerable sea surface temperature and wind-chill conditions. Moreover, in waters to the west of the United Kingdom there appears to be a reduced likelihood of rapid SAR response and of post-ditching survival (MSJ Reilly, Edinburgh conference, 1985). Response to the catastrophic loss of the Air India Boeing 747 south west of Ireland showed that four hours elapsed before the first helicopter arrived (A Sneddon, Edinburgh conference, 1985). If survivors from a controlled ditching in this locality failed to board aircraft liferafts, drowning or hypothermia would supervene even in summer sea surface temperatures. ${ }^{27}$ The relative safety of the liferaft, however, does not guarantee survival. 6970

Under the 1974 Convention on the Safety of Life at Sea, the United Kingdom is required to provide a search and rescue organisation for ships, aircraft, and individuals in distress. The last commissioned and publicly available official review of the civil maritime search and rescue system ${ }^{71}$ expressed concern about organisational and locational aspects which remain unchanged. ${ }^{72}$ This was despite reorganisation which began in 1978. More recent evaluation of the spatial efficiency of search and rescue helicopter distribution showed improvements since 1970 (particularly in the northern North Sea) but crucial gaps in coverage (in north west Scotland) and transit time deficiencies were identified (MSJ Reilly, Edinburgh conference). The potential of pre-1981 stand by vessels to perform adequately during offshore emergency rescue or installation evacuation has been investigated and criticised $^{73}$ and inadequacies in true emergencies have been exposed. ${ }^{74}$ Shortcomings in poorly adapted life saving apparatus, designed for entirely different purposes, were shown when the "Alexander Kielland" platform capsized in 1980 and 123 Norwegian workers died. ${ }^{75}$

The contention that concern for the safety of shipping has grown in recent years but only “... as an aftermath of maritime disasters rather than in anticipation of them..."6 is too simplistic but there is evidence to lend partial support for this view. ${ }^{76-78}$ The reality is more complex: the United Kingdom has taken major initiatives-notably in the search and rescue arena. Nevertheless, parts of the maritime frontier are forgotten or, at best, command less priority. Fishing industry safety, particularly the investigation and prevention of losses, clearly demands scrupulous attention: policy objectives should be formulated, published, discussed more widely and openly, and their implementation independently monitored.

A recent review of the functions and interconnections of United Kingdom organisations concerned with maritime safety concluded that responsibilities are excessively fragmented and that the boundaries of areas of jurisdiction of these organisations are irrelevant to current safety needs. ${ }^{6}$ Furthermore, the United Kingdom approach "differs radically" from that of other major maritime nations. As for a wider preventive strategy, these authors also point to the UK Civil Aviation Authority, established partly to rationalise air safety functions, as a practical model for the government to replicate in pursuit of enhanced maritime safety. The need for a statutory marine safety authority was recommended more than 15 years ago. ${ }^{79}$ This advice was ignored. Now, the United Kingdom would not be able to boast that it had the first Civil Marine Authority but, given time and a fair wind, it could have the best. Do we have the imagination, the purpose, and the will?

MARK S J REILLY

Department of Community Medicine,

University of Dundee,

Ninewells Hospital and Medical School,

Dundee DDI 9SY.

\section{References}

1 Home Office. Report of the working party on water safety. London: HMSO, 1977.

2 Royal Society for the Prevention of Accidents. Water safety outdoorsadvisory notes for local authorities and others. Birmingham: RoSPA, 1983. 
3 Department of Transport. HM Coastguard annual incident statistics, 1985. London: HM Coastguard, 1986.

4 Couper $\mathrm{AD}$, ed. The Times atlas of the oceans. London: Times Books Limited, 1983.

5 Cabinet Office. Civil service year book 1985. London: HMSO, 1985.

6 Oliver GBM, Lyon PR. Maritime safety in British waters - the shore-based organisation. National Ports Council Bulletin 1981;16:31-96.

7 Department of Transport. Principal Acts and regulations on merchant shipping. (Merchant shipping notice No M1154.) London: HMSO, 1985

8 Department of Transport. Merchant shipping notices current on 30th April 1985. (Merchant shipping notice No M1181.) London: HMSO, 1985.

9 Burgoyne $\mathrm{JH}$, chairman. Offshore safety-report of the committee. London: HMSO, 1980:appendix 10. (Text of Prime Minister's statement on offshore safety responsibility made on 30 July 1976.)

10 Burgoyne $\mathrm{JH}$, chairman. Offshore safety-report of the committee. London: HMSO, 1980:appendix 11. (An agency agreement between the Health and Safety Commission and the Secretary of State for Energy.)

11 Burgoyne $\mathrm{JH}$, chairman. Offshore safety--report of the committee. London: HMSO, 1980.

12 Crockford GW, Dyer DF. A four year survey of mortality in British divers. In: Proceedings of the 8th symposium of the Underwater Association, Polytechnic of North London, 20-21 September 1974. London: The Underwater Association, 1975:178-82.

13 British Medical Association Scottish Council. Report of the working party on the medical implications of oil related industry. Edinburgh: BMA, 1975.

14 Riddle HFV. A general survey of the medical problems associated with the offshore oil developments in the North Sea. In: Proceedings of an ad hoc meeting to discuss underwater physiology and other biomedical problems related to offshore activities. Glasgow: University of Glasgow, Medical Research Council, 1975.

15 Morrall A. Capsizing of small trawlers. Transactions of the Royal Institution of Naval Architects 1980;122:71-101.

16 Reilly MSJ. The safety of UK fishing vessels, 1961-80. Journal of Navigation 1984;37:60-82.

17 Bishop RED. A note on the safety of fishing vessels. The Naval Architec (in press).

18 Holland-Martin D. Trawler safety-final report of the committee of inquiry into trawler safety. London: HMSO, 1969.

19 Fishing vessels (safety provisions) rules, 1975. London: HMSO, 1975.

20 Department of Transport. Casualties to vessels and accidents to men. London: HMSO, 1981-5.

21 Reilly MSJ. Have "formal investigations" into fishing vessel losses ceased? Br J Ind Med 1987:44:7-13.

22 Civil Aviation. (Investigation of accidents) regulations 1983. London: HMSO, 1983. (SI 1983 No 551.)

23 Reilly MSJ. Mortality from occupational accidents to United Kingdom fishermen, 1961-80. Br J Ind Med 1985;42:806-14.

24 Sea Fish Industry Training Council. Annual review 1984-85. Hull: Sea Fish Industry Authority, 1985.

25 Keatinge WR. Death after shipwreck. Br Med J 1965;ii:1537-41.

26 Golden FSC. Recognition and treatment of immersion hypothermia. Proc $R$ Soc Med 1973;66:1058-61.

27 Keatinge WR. Accidental immersion, hypothermia and drowning. The Practitioner 1977;219:183-7.

28 Keatinge WR. Role of cold in immersion accidents. In: Adam JM, ed. Hypothermia ashore and afloat. Proceedings of the third international action for disaster conference, Aberdeen, 1979. Aberdeen: Aberdeen University Press, 1981:30-6.

29 Golden FSC, Hervey GR. The "after-drop" and death after rescue from immersion in cold water. In: Adam JM, ed. Hypothermia ashore and afloat. Proceedings of the third international action for disaster conference. Aberdeen, 1979. Aberdeen: Aberdeen University Press, 1981:37-56.

30 Golden FSC. Hypothermia: a problem for North Sea industries. J Soc Occup Med 1976;26:85-8.

31 Roythorne C. Cold in North Sea operations. In: Adam JM, ed. Hypothermia ashore and afloat. Proceedings of the third international action for disaster conference. Aberdeen. 1979. Aberdeen: Aberdeen University Press 1981:66-74.

32 Cross JH. Survival and rescue at sea. In: Adam JM, ed. Hypothermia ashore and afloat. Proceedings of the third international action for disaster conference, Aberdeen, 1979. Aberdeen: Aberdeen University Press, 1981 125-33.

33 Department of Trade. Report of the working group on the occupational safety of fishermen. London: HMSO, 1979.

34 Board of Trade. Safety of seamen-report of the steering committee on the safety of merchant seamen. London: HMSO, 1970.

35 Health and Safety Executive. The loading and unloading of fishing vessels regulations. London: HMSO, (in press). (Consultative document.)

36 Safety at Sea Act 1986. London: HMSO, 1986. (Bill 142.)

37 Department of Transport. The merchant shipping (medical examination) regulations 1983. S1 1983, No 808. (Merchant shipping notice No M1144.) London: HMSO, 1984

38 Health and Safety Executive. A guide to the diving operations at work regu- lations 1981. London: HMSO, 1981. (Health and safety series bookle HS(R)8.)

39 The Air Navigation Order 1985. London: HMSO, 1985. (SI 1985 No 1643.?

40 Grewe HE. The psychological and physical strain on the crews of fishing vessels: health criteria to be applied in assessing suitability for work aह sea. In: Proceedings of the seminar on integrated safety and the prevention ${ }^{+}$ of accidents in the sea fishing industry, Lorient, France, 15-18 May, 19870 Luxembourg: Commission of the European Communities, 1985.

41 Moore SRW. The mortality and morbidity of deep sea fishermen sailing fron Grimsby in one year. Br J Ind Med 1969;26:25-46.

42 Cadenhead RMcN. Hospital admissions of fishermen from the fishin $\vec{D}$ grounds around the Shetland Islands. J Soc Occup Med 1976;26:127-31

43 Collacott RA. Risks to trawler fishermen in Orkney waters. $J$ R Coll Geß Pract 1977;27:482-5.

44 Anonymous. Banff fishermen rescued from sea by shipmate. Press an $\vec{b}$ Journal 7 June 1984.

45 Cross T. The health of British trawlermen on the Arctic fishing grounds. Soc Occup Med 1985;35:55-61.

46 Read JF. Shipping casualties around the British Isles 1970-1979. London National Maritime Institute, 1981. (Report 106, NMI.)

47 Civil Aviation Authority. Review of helicopter airworthiness. (Report of the helicopter airworthiness review panel (HARP) of the airworthines requirements board.) London: Civil Aviation Authority, 1984. (CAPA 491.)

48 Postlethwaite A. Helicopters in the dock. Flight International 1986;129:22-6

49 Harding RM, Mills FJ. Special forms of flight 2: helicopters. Br Med 6 1983;287:346-9.

50 Anton DJ. A review of UK registered helicopter ditchings in the North SeaInternational Journal of Aviation Safety 1984;2:55-63.

51 Leese WLB. Considerations of disaster caused by helicopter ditchings. In Adam JM, ed. Hypothermia ashore and afloat. Proceedings of the thir international action for disaster conference, Aberdeen, 1979. Aberdeend Aberdeen University Press, 1981:75-82.

52 Merchant Shipping (Medical Scales) Regulations 1974. (SI 1974 No 1193.) London: HMSO, 1974.

53 Merchant Shipping (Medical Scales) (amendment) Regulations 1975. (SPO 1975 No 1581.) London: HMSO, 1975.

54 Merchant Shipping (Medical Scales) (amendment) Regulations 1980. (SD 1980 No 407.) London: HMSO, 1980.

55 Fee JPH, Moore J. Emergencies at sea. Br Med J 1985;291:344

56 Bourne WRP. Emergencies at sea. Br Med J 1985;291:545.

57 Jones AG. Emergencies at sea. Br Med J 1985;291:827.

58 Gleadhill DNS. Emergencies at sea. Br Med J 1985;291:1046.

59 Bourne WRP. Emergencies at sea. Br Med J 1986;292:1133-4.

60 Anderson TB. Emergencies at sea. Br Med J 1986;292:1671.

61 Beale JD. General practitioner in rescue helicopters. Br Med J 1981 283:959-60.

62 Shepherd FGG. Medicine and the North Sea -emergencies for the generat practitioner. J Soc Occup Med 1976;26:50-2.

63 Parry-Jones OC. General practitioner on the lifeboat. Br Med 1981;282:1765-6.

64 Cox RAF. Offshore medicine. Medical care of employees in the offshore oit industry. Berlin, Heidelberg. New York: Springer-Verlag, 1982.

65 Nautical Institute. Evacuation and rescue from high-sided ferries and passenger vessels. Journal of the Nautical Institute 1986;May:9-11.

66 Ramsden JM. Oceanic twins: how safe? Flight International 1983;124:1674

67 Civil Aviation Authority. Extended range twin operations. ((ETOPS) CAF 513.) London: Civil Aviation Authority, 1986.

68 Moxon J. Engines for twins: how reliable? Flight International 1983? 124:1678-9.

69 Report of Court No 8066 mv Lovat (ON 360735). London: HMSO, 1977. 을

70 Pugh LGC. Isafjordur trawler disaster: medical aspects. $\mathrm{Br}$ Med J 1968: i:826-9.

71 Board of Trade. Marine search and rescue organisation--report of the commit tee to review the marine $S A R$ organisation of the United Kingdom. London HMSO, 1970.

72 Department of Transport. United Kingdom search and rescue (UKSARN handbook. London: HMSO, 1985.

73 Department of Energy. Report and draft guidance notes on the use and effectiveness of stand-by vessels (rescue ships) in offshore operations (Offshore technology paper 9 prepared for the DEn by Holloborte Hibbert and Associates Limited). London: CIRIA, 1981.

74 Scott RJD. Fatal accident inquiry. Determination of the causes and circum stances of the death of JB Stephen, I April, 1981. Aberdeen: Aberdeens Sheriff Court, 1982.

75 Norges Offentlige Utredninger. "Alexander Kielland"-ulykken. (NOU 1981:11.) Oslo: Universitetsforlaget, 1981.

76 Report of Court No 8062 mv Burtonia (ON 300222). London: HMSO, $1974 \frac{7}{+1}$

77 Department of Trade. Sikorsky S.61N helicopter G-BBHN. Report on th accident in the North sea northeast of Aberdeen on lst October, 1977(D) London: HMSO, 1978.

78 Forbes H, Laing M. Myatt J. Fastnet race inquiry report. London: Roya Yachting Association and Royal Ocean Racing Club, 1979.

79 Report of the committee of inquiry into shipping. London: HMSO, 1970 